\title{
QUANDO A MORAL É ELEMENTO DETERMINANTE NAS DECISÕES SOBRE CRIMES DE VIOLÊNCIA SEXUAL: O SOLIPSISMO EPISTEMOLÓGICO
}

\author{
WHEN MORAL IS A DETERMINING ELEMENT IN DECISIONS ON \\ CRIMES OF SEXUAL VIOLENCE: \\ EPISTEMOLOGICAL SOLIPHISM
}

\section{CUANDO LA MORAL ES UN ELEMENTO DETERMINANTE EN DECISIONES SOBRE LOS CRÍMENES DE LA VIOLENCIA SEXUAL: SOLIPISMO EPISTEMOLÓGICO}

\begin{abstract}
EDNA RAQUEL HOGEMANN
http://orcid.org/0000-0003-3276-4526 / http://lattes.cnpq.br/3237502473386597 / ershogemann@gmail.com Universidade Estácio de Sá (UNESA) e Universidade Federal do Estado do Rio de Janeiro (UNIRIO).

Rio de Janeiro, RJ, Brasil.
\end{abstract}

\begin{abstract}
ACÁCIA GARDÊNIA SANTOS LELIS
https://orcid.org/0000-0002-4064-341X / http://lattes.cnpq.br/9461246232620696 / ershogemann@gmail.com Universidade Federal do Estado do Rio de Janeiro (UNIRIO).

Rio de Janeiro, RJ, Brasil.
\end{abstract}

\begin{abstract}
RESUMO
Analisa em que medida os valores morais de ordem subjetiva influenciam as decisões dos aplicadores do Direito em casos como os de violência sexual praticados contra crianças e adolescentes pobres e periféricos. Para essa pesquisa, o método de abordagem utilizado pelas autoras é o fenomenológico, a partir de uma abordagem crítico-reflexiva sobre a ocorrência de um solipsismo epistemológico. A partir dele, observa-se que os intérpretes da norma tendem a não observar que o Direito deve ser dissociado da moral, que ele deve ter autonomia e sua aplicação deve ser independente de julgamentos morais moral, conforme entendimento de Streck, em oposição a Dworkin. A pesquisa conclui pela urgente necessidade da mudança do comportamento dos intérpretes do Direito, que devem decidir em conformidade com a lei, ainda que suas ideias e convicções sejam permeadas por valores diversos.
\end{abstract}

Palavras-chave: Direito; Moral; Solipsismo; Violência sexual

\section{ABSTRACT}

It analyzes the extent to which moral values of a subjective order influence the decisions of law enforcers in cases such as sexual violence against poor and peripheral children and adolescents. For this research, the method of approach used by the authors is the phenomenological, from a critical-reflexive approach on the occurrence of an epistemological solipsism. As from this, it is observed that interpreters of the norm tend not to observe that the Law must be dissociated from the moral, that it must have autonomy and must have independent application of the morality, according to Streck's understanding, as opposed to Dworkin. The research concludes by the urgent need of changing the behavior of law interpreters, who must decide in accordance with the law, although their ideas and convictions are permeated by diverse values.

Keywords: Law; Moral; Solipsism; Sexual violence. 


\section{RESUMEN}

Se analiza en qué medida los valores morales de orden subjetivo influencian las decisiones de los aplicadores del Derecho en casos como los de violencia sexual practicados contra niños y adolescentes pobres y periféricos. Para esta investigación, el método de abordaje utilizado por las autoras es el fenomenológico, a partir de un enfoque críticoreflexivo sobre la ocurrencia de un solipsismo epistemológico. A partir de eso, se observa que los intérpretes de la norma tienden a no observar que el Derecho debe ser disociado de la moral, que debe tener autonomía y su aplicación independiente de la moral, según el entendimiento de Streck, en oposición a Dworkin. La investigación concluye por la urgente necesidad del cambio del comportamiento de los intérpretes del Derecho, que deben decidir de conformidad con la ley, aunque sus ideas y convicciones sean impregnadas por valores diversos.

Palabras clave: Derecho; moral; solipsismo; Violencia sexual.

\section{SUMÁRIO}

INTRODUCCÃO; 1. SOBRE O ESTUPRO COLETIVO OCORRIDO NO RIO DE JANEIRO E OUTROS CASOS; 2. A RELATIVIZAÇÃO E O COMPROMETIMENTO DO DIREITO PELA MORAL; 3. A MORAL COMO CONDICIONANTE DO DIREITO; 4. EM QUE MEDIDA A MORAL DEVE INFLUENCIAR A INTERPRETAÇÃO DO DIREITO?; CONCLUSÃO; REFERÊNCIAS

\section{INTRODUÇÃO}

O presente ensaio promove uma análise sobre a influência subjetiva dos valores morais nos intérpretes do Direito, de forma a realizarem uma interpretação da norma por meio da utilização de uma hermenêutica jurídica canhestra, movida ou em acordo com convicções pessoais e subjetivas, com grau zero de sentido jurídico-científico.

A fim de comprovar a hipótese aqui suscitada, as autoras trazem à discussão o fato ocorrido na cidade do Rio de Janeiro, com uma adolescente que foi estuprada, supostamente por mais de 30 (trinta) homens. ${ }^{1}$ Este é o pano de fundo para análise de uma hermenêutica jurídica

\footnotetext{
${ }^{1}$ A jovem de 16 anos que foi violentada por, pelo menos, 30 homens, em uma comunidade da Zona Oeste do Rio de Janeiro, deu detalhes sobre as agressões que sofreu em depoimento à Delegacia de Repressão aos Crimes de Informática (DRCl), ao qual a revista 'Veja' teve acesso.

A adolescente teria ido até a casa de um rapaz com quem se relacionava há três anos, no último sábado (21). Ela se lembra de estar a sós na casa dele e só se lembra que acordou no domingo (22), em uma outra casa, na mesma comunidade, com 33 homens armados com fuzis e pistolas. Ela conta no depoimento ao qual a "Veja" teve acesso, que estava dopada e nua.

A jovem conta ainda que foi para casa de táxi, após o ocorrido. Ela admitiu que faz uso de drogas, mas afirmou que não utilizou nenhum entorpecente no sábado (21).

$\mathrm{Na}$ terça (24), ela descobriu que imagens suas, sem roupas e desacordada, circulava na internet. A jovem contou ainda que voltou à comunidade para buscar o celular, que fora roubado.

Ela passou por exames de corpo de delito no Instituto Médico-Legal nesta quinta (26) e foi levada para o Hospital Souza Aguiar, no Centro, onde passou por exames e tomou um coquetel de medicamentos para evitar a contaminação por doenças sexualmente transmissíveis. (G1. Vítima de estupro coletivo no Rio conta que acordou dopada e nua. Disponível em: http://g1.globo.com/rio-dejaneiro/noticia/2016/05/vitima-de-estupro-coletivo-no-rio-conta-que-acordou-dopada-e-nua.html. Acesso em: 10 maio 2017.)
} 
ISSN 1981-3694

(DOI): $10.5902 / 1981369431630$

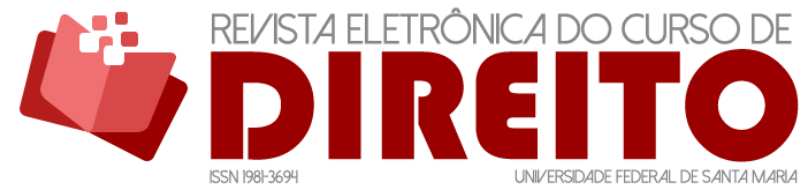

QUANDO A MORAL É ELEMENTO DETERMINANTE NAS DECISÕES SOBRE CRIMES DE VIOLÊNCIA SEXUAL: O SOLIPSISMO EPISTEMOLÓGICO

EDNA RAQUEL HOGEMANN ACÁCIA GARDÊNIA SANTOS LELIS

alijada de qualquer conhecimento científico, fundada em uma interpretação discricionária, que buscou "adequar" o Direito pela moral.

A partir do método de investigação fenomenológico de Husserl, que tem o propósito de apreender o fenômeno - a saber, a aparição das coisas à consciência, de modo rigoroso e de uma hermenêutica universal que leva em conta o saber e pensar os fatos do mundo face à universalidade linguística, como concebida por Schleiermacher,$-^{2}$ analisa-se a atuação do delegado de polícia do Rio de Janeiro que iniciou o inquérito policial para investigar o estupro coletivo, o qual, em suas primeiras declarações, parecia dar um rumo às investigações no sentido de culpabilizar a vítima pela violência sofrida. Sua manifestação dava indícios claros de valoração moral autônoma, com uma ideia rasa e promíscua do Direito, blindada por valores solipsistas $^{3}$ epistemológicos que se mostra como um desserviço ao Estado Democrático de Direito, por ignorar os valores e princípios fundadores da ordem constitucional.

Inicialmente, apresenta-se o fato ocorrido no Rio de Janeiro, que será o pano de fundo do presente estudo, mostrando alguns detalhes das partes envolvidas, a partir de notícias veiculadas na mídia nacional. Através de coleta das informações trazidas sobre o fato, busca-se apresentar a propositura de uma Hermenêutica de Valores na condução dos trabalhos pelo delegado responsável pelo caso.

Analisa-se a influência da moral no Direito, apresentada por Dworkin em sua obra Justiça de Toga, ao indagar se as convicções morais de um juiz devem influenciar seus julgamentos acerca do que é o Direito, e suas conclusões - na contramão do entendimento de Lênio Streck -, que no conjunto de sua obra, compreende que o Direito deve ser independente da moral.

Em razão da importância desse tema, que se revela cada dia mais atual, ${ }^{4}$ a proposta trazida pelo presente estudo almeja contribuir com alguns elementos para o avanço na elucidação da polêmica que envolve as questões conflitantes entre o Direito e a moral, utilizando, para tal, Lênio Streck e Ronald Dworkin, como referenciais teóricos.

\footnotetext{
2 SCHLEIERMACHER, Friedrich D.E. Hermenêutica: arte e técnica da interpretação. 5. ed. Trad. Celso Reni Braida. Bragança Paulista: Editora Universitária São Francisco, 2006.

${ }^{3}$ Segundo Mora "El idealismo subjetivo gnoseológico, que reduce todos los objetos, como objetos de conocimiento, a contenidos de conciencia, y el idealismo metafísico, que niega la existencia o, mejor dicho, la subsistencia, del mundo externo, conducen al solipsismo". MORA, José Ferrater. Diccionario de Filosofía. Barcelona: Ariel, 2001.

${ }^{4}$ É exemplo da relevância dessa temática que envolve a violência de gênero e as decisões judiciais, o estudo pioneiro promovido pelas autoras Silvia Pimentel, Di Giorgi e Flávia Piovesan intitulado "A figura/personagem da mulher em processos de família". (PIMENTEL, Silvia. DI GIORGI, Beatriz. PIOVESAN, Flávia. A Figura/Personagem Mulher em Processos de Família. Porto Alegre: Fabris, 1993).
} 


\section{SOBRE O ESTUPRO COLETIVO OCORRIDO NO RIO DE JANEIRO E OUTROS CASOS}

O estupro coletivo ocorrido na Zona Oeste do Rio de Janeiro, no dia 21 de maio de 2016, do qual foi vítima uma adolescente de 16 anos de idade e que ganhou notícias por meio das redes sociais, teve repercussão nacional e internacional. Em verdade, esse fato representa milhões de outros cotidianamente noticiados em delegacias do Brasil, e principalmente aqueles não noticiados, que ficam fora das estatísticas oficiais de violência sexual. Semelhante a tantos outros casos, o caso do estupro coletivo ocorrido no Rio de Janeiro será apresentado em breves linhas para proporcionar o ingresso no tema em análise.

No dia 21 de maio de 2016, uma adolescente de 16 anos de idade foi vítima de estupro coletivo na cidade do Rio de Janeiro, fato este noticiado com a exibição de um vídeo gravado e veiculado nas redes sociais pelos supostos autores do crime. Segundo noticiado na mídia, o fato chegou ao Ministério Público do Rio de Janeiro por meio de uma denúncia anônima à Ouvidoria, que, encaminhando o vídeo veiculado na internet, juntou ainda prints de redes sociais onde foram veiculados. Além dessa denúncia, que trouxe prova do alegado, mais de 800 denúncias se seguiram na Ouvidoria do Ministério Público sobre o mesmo fato.

Segundo informações constantes em reportagem de Leslie Leitão para o website da revista Veja, o estupro coletivo ocorreu dentro do Morro da Barão, na Praça Seca, Bairro de Jacarepaguá. 0 vídeo, de pouco mais de 40 segundos, foi gravado pelos próprios agressores durante a prática delitiva e se propagou rapidamente em grupos em redes sociais, tais como WhatsApp, Twitter e Facebook. Leslie Leitão informa que:

C.B.T.P. namorava um homem suspeito de integrar o tráfico da favela, identificado apenas pelo apelido de Petão, e que estudava com ela numa escola do bairro da Taquara. Na madrugada do último sábado, dia 21, ela saiu da casa onde morava com a mãe e o filho de 3 anos para ir a um baile funk na favela. Só retornou dois dias mais tarde, segundo a família visivelmente drogada e com roupas masculinas, já que as suas haviam sido roubadas: "Ela foi tomar um banho e dormiu", disse a mãe em depoimento. A.T. contou também que procurou o Conselho Tutelar para tentar internar a filha compulsoriamente após o ataque ${ }^{5}$.

${ }^{5}$ LEITÃO, Leslie. Polícia tenta identificar bandidos que praticaram estupro coletivo em favela do Rio de Janeiro. Veja.com. (26/05/2016). Disponível em: http://veja.abril.com.br/noticia/brasil/policia-tenta- 
ISSN 1981-3694

(DOI): $10.5902 / 1981369431630$

A "viralização" do vídeo motivou muitas pessoas a denunciarem o fato à Polícia do Rio de Janeiro e solicitar as providências cabíveis. O fato repercutiu na imprensa nacional e internacional devido a sua gravidade e ao sentimento de indignação e de revolta que despertou na população. Antes mesmo de a vítima ter conhecimento da violência que sofrera, o fato já era de conhecimento público e já estava nas mãos das autoridades para apurarem os fatos, conforme noticiou a jornalista:

A história se espalhou rapidamente pelas redes. Um homem chegou a posar para um selfie com C. ao fundo, nua e jogada na cama. A cena filmada e postada pelos criminosos, aliás, foi o que ajudou a polícia a identificar onde o fato havia ocorrido antes mesmo de a jovem aparecer para prestar depoimento. ${ }^{6}$

O vídeo veiculado nas redes sociais mostra alguns homens zombando da vítima e de sua condição, trazendo, ainda, cenas de extrema barbárie, com a adolescente desacordada, completamente inconsciente. A vítima, segundo informações provenientes da mídia, havia sido dopada e, sem qualquer condição de manifestação de seu consentimento, abusada sexualmente por vários homens. As falas e imagens dos agressores constantes nos vídeos são auto incriminadoras, pois um deles afirma que "mais de 30 engravidou" (sic), e, no momento seguinte, mostra os criminosos, que aparentam estar dentro de uma casa com pelo menos um cômodo e uma sala, continuando a zombar da adolescente, ainda desacordada. Um deles abre as pernas da jovem para tentar mostrar a genitália machucada e afirma: "olha como é que ela tá! Sangrando" (sic). ${ }^{7}$

Após tomar conhecimento do vídeo e de sua divulgação na internet, a vítima prestou depoimento à Polícia, confirmando o que fora veiculado nas mídias sociais, conforme se vê nos documentos a seguir, identificados como Figuras 01 e 02:

identificar-bandidos-que-praticaram-estupro-coletivo-em-favela-do-rio-de-janeiro. Acesso em: 04 jul. 2016.

${ }^{6}$ LEITÃO, Leslie. Polícia tenta identificar bandidos que praticaram estupro coletivo em favela do Rio de Janeiro. Veja.com. (26/05/2016). Disponível em: http://veja.abril.com.br/noticia/brasil/policia-tentaidentificar-bandidos-que-praticaram-estupro-coletivo-em-favela-do-rio-de-janeiro. Acesso em: 04 jul. 2016.

7 LEITÃO, Leslie. Polícia tenta identificar bandidos que praticaram estupro coletivo em favela do Rio de Janeiro. Veja.com. (26/05/2016). Disponível em: http://veja.abril.com.br/noticia/brasil/policiatenta-identificar-bandidos-que-praticaram-estupro-coletivo-em-favela-do-rio-de-janeiro. Acesso em: 04 jul. 2016. 
Ilustração 01 - Termo de Declaração de C.B.T.P. à Polícia Civil do Rio de Janeiro.

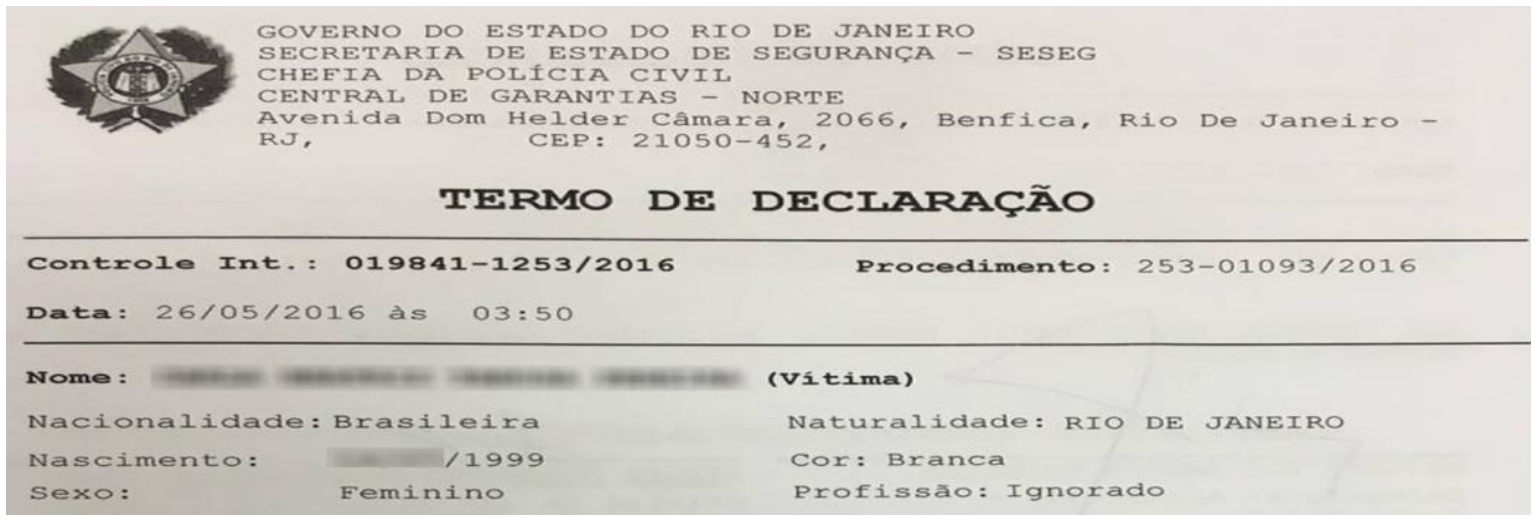

Fonte: Leitão (2016).

Figura 02 - Termo de Declaração de C.B.T.P. à Polícia Civil do Rio de Janeiro.

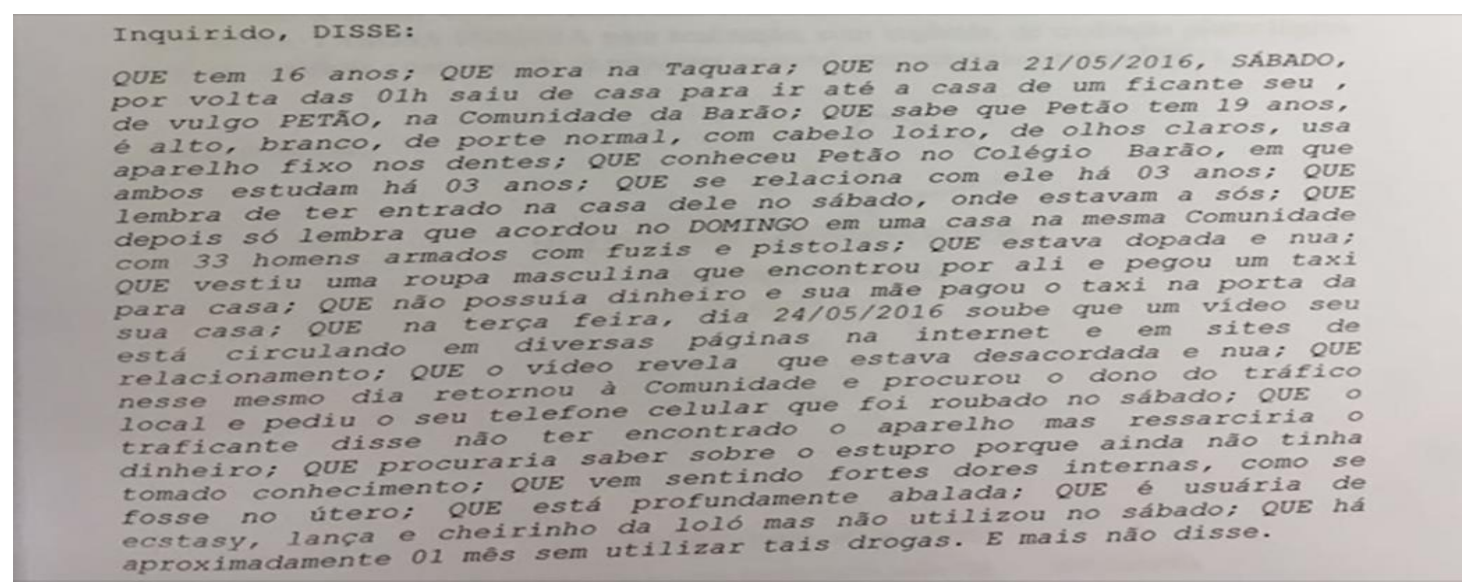

Fonte: Leitão (2016).

Em outra edição, a revista Veja publicou mais informações sobre o crime, informando aos internautas detalhes sobre a apuração dos fatos:

Segundo narra nota do MP, em 21 de maio, 'desacordada e sob efeito de álcool e substâncias entorpecentes [...], a vítima manteve relações sexuais com Raí. Sob a permissão de Sérgio, chefe do tráfico na comunidade, Moisés Camilo a levou para um local afastado 90 metros dali, conhecido como "abatedouro"'. Ali, sem poder oferecer resistência, a jovem 'tornou-se presa fácil e objeto de abuso de Raí, Raphael e Moisés, bem como do adolescente conhecido como Perninha, também integrante da quadrilha'.

Segundo o MP, 'a vítima sofreu abuso por várias horas, até a noite seguinte, sempre de forma conjunta pelos denunciados'. 'Raphael chegou ainda a manipular de maneira debochada as nádegas da vítima, introduzido um batom em sua 
ISSN 1981-3694

(DOI): $10.5902 / 1981369431630$

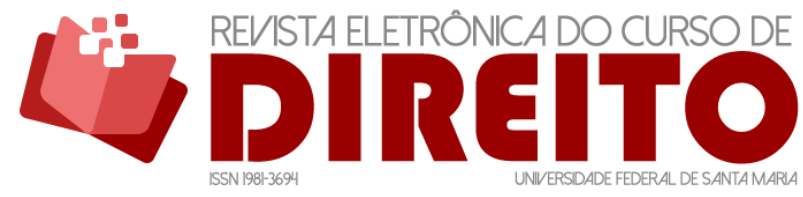

QUANDO A MORAL É ELEMENTO DETERMINANTE NAS DECISÕES SOBRE CRIMES DE VIOLÊNCIA SEXUAL: O SOLIPSISMO EPISTEMOLÓGICO

EdNA RAQuel HOGEMANN ACÁCIA GARDÊNIA SANTOS LELIS

vagina', detalha a nota do Ministério Público. 'Raphael e Raí ainda registraram o crime em vídeo, com o telefone celular do primeiro, tendo Raí transmitido imagens para um grupo de amigos por meio do aplicativo WhatsApp'. ${ }^{8}$

A notícia, que chocou pela brutalidade cometida contra a adolescente vitimada de estupro por mais de 30 homens, gerou também comentários negativos nas redes sociais, onde foram divulgadas informações sobre sua vida pessoal, segundo as quais a menor era usuária de drogas, namorada de um traficante e mãe de um menino de três anos de idade. Várias postagens feitas nas redes sociais continham comentários negativos relacionados à vítima, com denotação sexista, machista e misógina, responsabilizando-a pelo estupro e naturalizando a conduta dos réus. Essa conduta, intrinsicamente relacionada à cultura do estupro - e dela decorrente -, será devidamente abordada na sequência.

\section{EM QUE MEDIDA A MORAL DEVE INFLUENCIAR A INTERPRETAÇÃO DO DIREITO?}

É legitimo ao operador do direito agir utilizando como parâmetro norteador suas convicções morais? Para Ronald Dworkin, essa questão é importante já que “[...] às vezes, não fica clara qual é a interpretação correta de uma série de decisões judiciais”. Acrescenta o autor que "[...] devemos atentar para essas diferentes maneiras em que a moral pode estar presente ao tomarmos nossas decisões acerca do que é o direito."

As posições de Ronald Dworkin e Lênio Streck revelam-se opostas. Para Dworkin,

A moral tem um papel a desempenhar em dois pontos distintos da teoria jurídica: no estágio teórico, quando se atribui valor à prática jurídica; e no estágio da decisão judicial, quando os juízes são instados a fazer a justiça [...]. Mas as duas inserções da moral são distintas. [...] em minha opinião, o valor da integridade que deveríamos atribuir á prática da justiça atravessa o estágio doutrinário e chega até o estágio da decisão judicial porque, argumento, a integridade exige que os juízes considerem a moral em alguns casos, inclusive neste, tanto para decidirem o que é o direito quanto sobre o modo de honrarem suas responsabilidades de juízes. ${ }^{10}$

8 VEJA. MP denuncia quatro por estupro coletivo no Rio. Disponível em: http://veja.abril.com.br/noticia/brasil/mp-denuncia-quatro-por-estupro-coletivo-no-rio. Acesso em: 04 jul. 2016.

${ }_{9}$ DWORKIN, Ronald. A Justiça de toga. São Paulo: Martins Fontes, 2010. p. 12.

${ }^{10}$ DWORKIN, Ronald. A Justiça de toga. São Paulo: Martins Fontes, 2010. p 31. 
ISSN 1981-3694

(DOI): $10.5902 / 1981369431630$

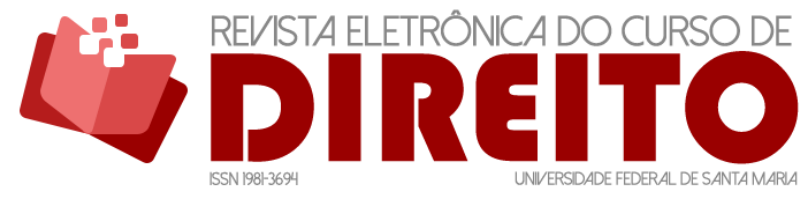

QUANDO A MORAL É ELEMENTO DETERMINANTE NAS DECISÕES SOBRE CRIMES DE VIOLÊNCIA SEXUAL: O SOLIPSISMO EPISTEMOLÓGICO

EdNA RAQuel HOGEMANN ACÁCIA GARDÊNIA SANTOS LELIS

Assim, conforme Dworkin, a moral pode ser sim um critério utilizado pelo julgador no intuito de se chegar à verdade-valor da proposição jurídica e, assim, atingir a correta aplicação do Direito. Para o autor, a moral desempenha um papel muito relevante na interpretação das normas jurídicas. A partir disso, as convicções pessoais, balizadas na consciência e nos valores morais, tornam-se ferramentas a serem utilizadas pelo operador do direito e são baseados em senso comum reproduzido por gerações, com mínimas alterações. Como afirma Streck “[...] o velho é tão forte que vela as mínimas possibilidades de o novo aparecer através de algumas frestas de sentido". ${ }^{11}$ A vagueza dos fundamentos empregados nos casos acima narrados, como já dito, fundados em senso comum, é como lanças que atingem o direito e a democracia.

Para Marilena Chauí:

Ciência distingue-se do senso comum porque este é uma opinião baseada em hábitos, preconceitos, tradições cristalizadas, enquanto a primeira baseia-se em pesquisas, investigações metódicas e sistemáticas, na exigência de que as teorias sejam internamente coerentes e digam a verdade sobre a realidade. A ciência é conhecimento que resulta de um trabalho racional. ${ }^{12}$

De acordo com Dworkin, seria ilegítima a utilização de valores morais pelos intérpretes do Direito, uma vez que o magistrado não pode ignorar quando considerar a lei injusta ou insensata, podendo usar seu poder político para impedir aquilo que considera injustiça ou ineficiência. Neste ponto o autor diverge de Streck, o qual entende que a Moral deve ser totalmente separada do Direito e pode não influenciar na decisão do magistrado. Não se podem conceber como justas interpretações fundadas em valores subjetivos desprovidos de cunho cientifico. $O$ ponto de vista de Streck é balizado em ciência, e não em senso comum, ao afirmar que:

Há uma impossibilidade de conhecimento dos conteúdos morais expressos nas condutas dos indivíduos. A única coisa que permanece uniforme em todos os sistemas morais é- tal qual acontece com os sistemas jurídicos- sua forma, seu caráter de norma. A forma da moral é estudada, segundo os postulados kelsenianos, pela ética; ao passo que a forma do direito é responsabilidade da ciência jurídica. ${ }^{13}$

\footnotetext{
11 STRECK, Lênio Luiz. Lições de crítica hermenêutica do direito. Porto Alegre: Livraria do Advogado, 2016. p.16.

12 CHAUÍ, Marilena. Convite à Filosofia. 3. Ed. São Paulo: Ática, 1995. p. 251.

${ }^{13}$ STRECK, Lênio Luiz. O que é isso - decido conforme a minha consciência. Porto Alegre: Livraria do Advogado, 2010. p. 262.
} 
ISSN 1981-3694

(DOI): $10.5902 / 1981369431630$

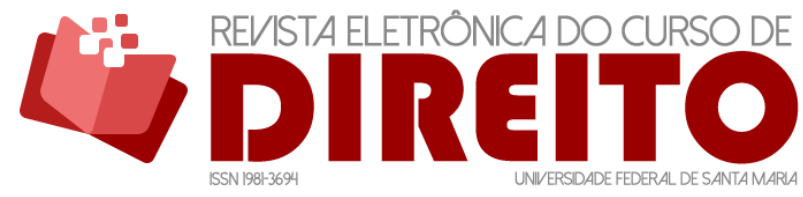

QUANDO A MORAL É ELEMENTO DETERMINANTE NAS DECISÕES SOBRE CRIMES DE VIOLÊNCIA SEXUAL: O SOLIPSISMO EPISTEMOLÓGICO

EdNA RAQuel HOGEMANN ACÁCIA GARDÊNIA SANTOS LELIS

A autonomia do direito pressupõe a determinabilidade dos sentidos como uma das condições para a garantia da própria democracia e de seu futuro. ${ }^{14}$ É imprescindível um palimpsesto para desvelar conceitos preconcebidos, e permitir a autonomia do Direito sem que este seja ameaçado. Nessa concepção, a liberdade e a autonomia da mulher devem ser respeitadas, sendo ela é livre no seu modo de vestir, falar, se expressar, na sua sexualidade, na sua vida pessoal, e em entre outros fatores. 0 exercício dessa liberdade só diz respeito à própria mulher, vez que não causa qualquer prejuízo a terceiros. Por essa razão não pode sofrer qualquer julgamento moral ou social, pelo exercício de sua liberdade.

A conduta do agressor, ao contrário, não pode ser compreendida como uma busca de um prazer natural, inerente à natureza humana. Ela pode ser interpretada como um ato de violência cultural, construída também sob uma cultura machista e sexista de manifestação da virilidade masculina. Nas palavras de Pierre Bordieu deve ser entendida "[...] como capacidade reprodutiva, sexual e social, mas também como aptidão ao combate e ao exercício da violência (sobretudo em caso de vingança), é, acima de tudo, uma carga."15

\section{A RELATIVIZAÇÃO E O COMPROMETIMENTO DO DIREITO PELA MORAL}

A violência sexual praticada contra a adolescente no Rio de Janeiro, como dito no item anterior, é utilizada neste estudo como uma demonstração da forma como intérpretes do Direito relativizam e comprometem o Direito pela moral, interpretando a norma legal diversamente do que se encontra insculpido na lei, criando uma nova norma jurídica, no caso concreto, de acordo com seus valores morais. 0 caso da adolescente no Rio é tão somente um recorte da situação de milhares de vítimas que são revitimizadas quando o caso chega ao Poder Público (nas mãos de juízes, promotores, delegados), em razão de valores morais conservadores e machistas.

O estupro narrado no presente estudo, além de provocar uma grande comoção social de indignação pela violência praticada contra a adolescente, também provocou uma discussão acalorada pela percepção social de parte da sociedade na intenção de culpar a vítima pelo ocorrido. A história de vida da vítima, que aos 13 anos de idade foi mãe, usuária de drogas e namorada de um traficante - fatos noticiados na imprensa -, fez com que parte da população

\footnotetext{
14 STRECK. Lênio Luiz. Lições de crítica hermenêutica do direito, Porto Alegre: Livraria do Advogado, 2016. p. 61.

15 BOURDIEU, Pierre. A dominação masculina. 2. ed. Tradução Maria Helena Kühner. Rio de Janeiro: Bertrande Brasil, 2002.p. 36.
} 
ISSN 1981-3694

(DOI): $10.5902 / 1981369431630$

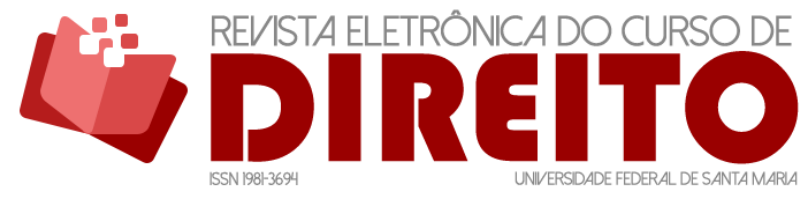

QUANDO A MORAL É ELEMENTO DETERMINANTE NAS DECISÕES SOBRE CRIMES DE VIOLÊNCIA SEXUAL: O SOLIPSISMO EPISTEMOLÓGICO

EdNA RAQuel HOGEMANN ACÁCIA GARDÊNIA SANTOS LELIS

julgasse a vítima como merecedora da violência sofrida e, assim, minimizasse a responsabilidade dos abusadores.

A configuração do delito de estupro ficou plenamente evidenciada haja vista a gravação do vídeo pelos abusadores, sua reprodução nas redes sociais, sem qualquer receio de represálias ou configuração de delito. A vítima se encontrava desacordada, sem possibilidade de reação aos atos contra ela praticados, e completamente alheia ao abuso sexual que sofria. No entanto, a configuração do delito ficou à mercê da população e do delegado que a julgaram em função de seu comportamento social, avaliando se ela era ou não "merecedora" de ser considerada vítima de estupro. Os acusados, assim como o delegado, entendiam - pela história de vida da vítima -, que ela não era inocente, o que ficou evidenciado pela naturalidade com que agiram os acusados ao gravar o vídeo da violência sexual, ao narrarem a conduta social da vítima. Essa percepção dos fatos pelos acusados é demonstrada através da fala de um deles no vídeo, ao afirmar que “[...] essa daqui é a famosa come rato da Barão”. ${ }^{16}$ A naturalização ainda é perceptível em função do comportamento dos acusados que, ao serem chamados a depor na delegacia, mostraram-se tranquilos, e, nas entrevistas concedidas aos noticiários, entre sorrisos, informaram que tudo seria esclarecido e que não haviam praticado estupro.

0 delegado responsável inicialmente pelo inquérito, titular da Delegacia de Repressão a Crimes de Informática (DRCl), Alessandro Thiers, chegou a conceder entrevista informando que ainda estava analisando se realmente havia ocorrido um estupro. A vítima, ao conceder entrevista à repórter Renata Ceribelli, programa Fantástico da Rede Globo de televisão, afirmou que se sentiu desrespeitada pelo delegado que tomou seu depoimento, e afirmou que:

O próprio delegado me culpou. Quando eu fui à delegacia eu não me senti à vontade em nenhum momento. Eu acho que é por isso que muitas mulheres não fazem denúncias. Tentaram me incriminar, como se eu tivesse culpa por ser estuprada. [...] Começando por ele, tinha três homens dentro de uma sala. A sala era de vidro, todo mundo que passava via. Ele colocou na mesa as fotos e o vídeo. Expôs e falou: 'me conta aí'. Só falou isso. Não me perguntou se eu estava bem, se eu tinha proteção, como eu estava. Só falou: 'me conta aí'. [...] Ele perguntou se eu tinha o costume de fazer isso, se eu gostava de fazer isso [sexo com vários homens]. ${ }^{17}$

\footnotetext{
${ }^{16}$ LEITÃO, Leslie. Polícia tenta identificar bandidos que praticaram estupro coletivo em favela do Rio de Janeiro. Veja.com. (26/05/2016). Disponível em: http://veja.abril.com.br/noticia/brasil/policiatenta-identificar-bandidos-que-praticaram-estupro-coletivo-em-favela-do-rio-de-janeiro. Acesso em: 04 jul. 2016.

${ }_{17} \mathrm{G} 1$. 'O próprio delegado me culpou', diz menor que sofreu estupro no Rio. Entrevista concedida a Renata Ceribelli, exibida no Fantástico em 29/05/2016. G1 Rio. (29/05/2016). Disponível em: http://g1.globo.com/rio-de-janeiro/noticia/2016/05/o-proprio-delegado-me-culpou-diz-menor-quesofreu-estupro-no-rio.html. Acesso em: 04 jul. 2016.
} 
Após a repercussão negativa da condução dos trabalhos pelo delegado Alessandro Thiers, a investigação do crime ficou a cargo da delegada Cristiana Bento, titular da Delegacia de Criança e Adolescente Vítima (DCAV), que, de imediato, reconheceu a prática de estupro e deu nova condução aos trabalhos. A delegada, em entrevista concedida ao site de notícias El País, quando indagada acerca da percepção dos abusadores da adolescente de que não teriam praticado qualquer delito, a mesma afirmou que:

\begin{abstract}
Em todo momento falavam a mesma coisa, que eles não tinham feito nada. 0 Raí [que vai responder pelos crimes de estupro de vulnerável, produção e transmissão de imagens pornográficas da adolescente] chegou na delegacia dizendo: "Eu estou tranquilo porque eu não estuprei ninguém". É algo cultural, isso tem que vir da escola. Você tem que ir no ensino fundamental, explicar o que é o estupro, como que um homem deve se comportar $[\ldots] .{ }^{18}$
\end{abstract}

A mudança foi essencial para dar novo rumo aos trabalhos. Isso também foi provocado pela campanha realizada nas redes sociais contra o que se intitula "cultura do estupro" encabeçada por movimentos feministas e estudiosas do tema. A cultura do estupro não é uma terminologia nova, ela remonta ao ano de 1974, quando as feministas lançaram o filme "Cultura do estupro", para aumentar a conscientização sobre a normalização da violência sexual na sociedade. A cultura do estupro é, então, compreendida como um contexto em que a violência sexual se torna normalizada e tolerada pelos membros da sociedade. Grazi Massoneto esclarece que:

Em 1974, o conceito cultura do estupro foi usado pelas feministas norteamericanas Noreen Connel e Cassandra Wilson em "Rape: The First Sourcebook for Women" (Estupro: O Primeiro Livro de Consulta para Mulheres). Foi uma das primeiras vezes em que o termo foi incluído em um livro. Para as autoras, despertar o olhar para a cultura do estupro seria um modo de eliminar tal mal da sociedade.

Para mim, despertar este olhar continua sendo mais do que importante, afinal, tal mal ainda não foi eliminado da sociedade. Mas voltemos ao ponto histórico: o tema começou a ganhar mais visibilidade no ano seguinte, em 1975, com o grupo New York Radical Feminists (Feministas Radicais de Nova lorque), que produziu palestras e conteúdo que inspiraram cineastas e escritoras. ${ }^{19}$

18 MASSONETTO, Grazi. O silencio que ecoa: a cultura do estupro no Brasil. Lugar de Mulher. (05/10/2015). Disponível em: http://lugardemulher.com.br/o-silencio-que-ecoa-a-cultura-do-estupro-nobrasil. Acesso em 03 jul 2016.

19 MASSONETTO, Grazi. O silencio que ecoa: a cultura do estupro no Brasil. Lugar de Mulher. (05/10/2015). Disponível em: http://lugardemulher.com.br/o-silencio-que-ecoa-a-cultura-do-estupro-nobrasil/. Acesso em 03 jul 2016. 
ISSN 1981-3694

(DOI): $10.5902 / 1981369431630$

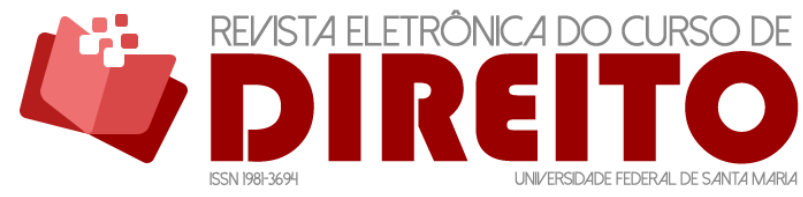

QUANDO A MORAL É ELEMENTO DETERMINANTE NAS DECISÕES SOBRE CRIMES DE VIOLÊNCIA SEXUAL: O SOLIPSISMO EPISTEMOLÓGICO

EdNA RAQuel HOGEMANN ACÁCIA GARDÊNIA SANTOS LELIS

A abordagem sobre o estupro aqui realizada foge da esfera puramente sociológica, na medida em que a ideia central proposta é a da compreensão da conduta da atuação do delegado, ao vincular valores morais como influenciadores à tipificação dessa conduta, sob a égide da metafísica do direito, e razão pela qual a cultura do estupro não será aqui objeto de discussão, ainda que seja de profunda relevância. É nessa perspectiva que se buscará uma compreensão dos aspectos morais relacionados ao Direito, que the atribuem um imperativo categórico da razão, não condicionado à moral. Por essa razão, não se pode condicionar o Direito a valores morais subjetivos, como por exemplo, o comportamento esperado de uma mulher na sociedade, de total recato, de conduta moral e social inabalável, sob pena de não ser reconhecida como vítima em caso de estupro. Assim, a caracterização do estupro independe da vida pregressa da vítima, na medida em que o que está em julgamento é o ato em si e tão somente o ato e a conduta do(s) agente(s) que o realizou(aram). Em relação à vítima, também só há que se ter em conta as questões vinculadas àquele ato perpetrado e nada mais.

Em ultima ratio, está em questão a eficácia (ou ineficácia) do instrumento normativo criado pelo Estado a fim de prevenir e compor os conflitos. Nas palavras de Edna Raquel Hogemann:

A eficácia é o nível de cumprimento da norma tendo em conta as relações sociais a elas referentes. Uma norma é considerada socialmente eficaz quando é observada por seus destinatários, apresentando os efeitos esperados quando de sua aplicação, seja porque impediu a instalação do conflito ou quando a sua violação é efetivamente punida pelo Estado. Em ambos os casos a previsão normativa é respeitada: seja de forma espontânea, seja através de uma intervenção coercitiva ou punitiva do Estado. ${ }^{20}$

Ressalta-se que o estupro, antes de tudo, é um ato de violência, alheio a um desejo sexual, a sentimento ou a atributos de sensualidade, vez que a vítima de estupro pode não ter atributos sensuais e comportamentais que despertem o desejo do estuprador, como é o caso de crianças e idosos. Ainda que presentes tais atributos, nada disso justifica tal violência, já que, para sua configuração, é necessário tão somente a ausência de consentimento da vítima ou a incapacidade de oferecê-lo.

Sobre as raízes culturais do estupro, afirmam Nayla Martins e Mariane Stival que "[...] o estupro é consequência do patriarcado". ${ }^{21}$ Acrescentam as autoras que o crime de estupro

\footnotetext{
${ }^{20}$ HOGEMANN, Edna Raquel. Sociologia jurídica e judiciária. Rio de Janeiro: SESES, 2015. p. 102.

${ }^{21}$ MARTINS, Nayla Louhana de Sá; STIVAL, Mariane Morato. Uma análise feminista: Estamos livres? Padrões de beleza, objetificação do corpo feminino e cultura de estupro. (2016). ISSUU. Disponível em: https://issuu.com/esmpgo/docs/19-artigo21_final_layout_1. Acesso em: 04 jul. 2016.
} 
ISSN 1981-3694

(DOI): $10.5902 / 1981369431630$

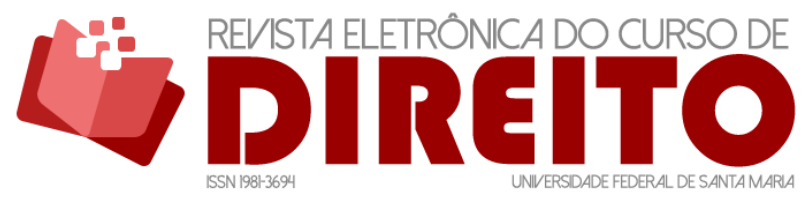

QUANDO A MORAL É ELEMENTO DETERMINANTE NAS DECISÕES SOBRE CRIMES DE VIOLÊNCIA SEXUAL: O SOLIPSISMO EPISTEMOLÓGICO

EDNA RAQUEL HOGEMANN ACÁCIA GARDÊNIA SANTOS LELIS

ocorre por conta de um gênero, que está direcionado às pessoas do sexo feminino, e que se elas não se "comportarem" esse será o seu destino. Assim, a sociedade exige um comportamento social irretocável e irreparável da mulher, que é assimilado e incorporado pela vítima, a qual, muitas vezes, não denuncia a violência sofrida, devido ao sentimento de culpa, por não corresponder àquela conduta social desejada.

Sob esse prisma, a mulher considerada é um objeto de prazer e satisfação sexual do homem. Se o seu comportamento não for condizente com o padrão social imposto, estará ela disponível para satisfação sexual, sem o direito de exigir comportamento diverso, e, portanto, é considerada "merecedora" da violência sofrida. O seu corpo é julgado como mero objeto de satisfação.

Em breve explanação, Grazi Massoneto define a cultura do estupro como:

Uma estrutura onde a mulher é culpada por qualquer constrangimento sexual que venha a passar. Uma sociedade que acha normal uma mulher ser constrangida na rua por uma cantada; normal uma mulher ser estuprada por estar bêbada ou usando roupas curtas; normal uma mulher ser forçada a fazer sexo com o companheiro, afinal, ele é seu marido ou namorado; normal uma mulher ser vista apenas como objeto para satisfazer as vontades alheias; normal uma mulher ser intimidada por homens heterossexuais quando é lésbica, porque na verdade ela tem que aprender a gostar de homem. ${ }^{22}$

Percebeu-se, no caso do estupro coletivo ocorrido no Rio de Janeiro, a avaliação do comportamento da vítima, não somente pelo delegado, como noticiado no presente ensaio, mas também pelos internautas que manifestaram suas opiniões nas redes sociais. Exemplificadamente, cita-se: “num país que se fabrica mini-putas, com uma farta erotização precoce e com severa infantilização da população reduzindo as responsabilidades" 23 e segue: “[...] não é de se surpreender esses lamentáveis casos de estupro”. ${ }^{24}$

22 MASSONETTO, Grazi. O silencio que ecoa: a cultura do estupro no Brasil. Lugar de Mulher. (05/10/2015). Disponível em: http://lugardemulher.com.br/o-silencio-que-ecoa-a-cultura-do-estupro-nobrasil. Acesso em 03 jul 2016.

23 LOBÃO. NUM PAÍS QUE SE FABRICA MINI-PUTAS,COM UMA FARTA EROTIZAÇÃO PRECOCE E COM SEVERA INFANTILIZAÇÃO DA POPULAÇÃO REDUZINDO AS RESPONSABILIDADES. [Local], 26 maio 2016. Twitter: @lobaoeletrico. Disponível em: https://twitter.com/lobaoeletrico/status/735983496104189952. Acesso em: 16 jun. 2019.

${ }^{24}$ COMENTÁRIO de Lobão sobre estupro gera polêmica: 'País que fabrica miniputas'. Diário de Pernambuco. $(27 / 05 / 2016)$. Disponível em: http://www.diariodepernambuco.com.br/app/noticia/divirtase/46,51,46,61/2016/05/27/internas_viver, 647160/comentario-de-lobao-sobre-estupro-gera-polemica-pais-que-fabrica-min.html. Acesso em 04 jul 2016. 
ISSN 1981-3694

(DOI): $10.5902 / 1981369431630$

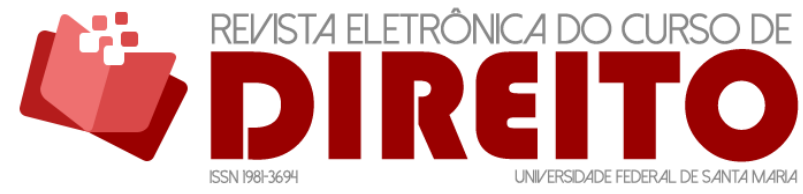

QUANDO A MORAL É ELEMENTO DETERMINANTE NAS DECISÕES SOBRE CRIMES DE VIOLÊNCIA SEXUAL: O SOLIPSISMO EPISTEMOLÓGICO

EDNA RAQUEL HOGEMANN ACÁCIA GARDÊNIA SANTOS LELIS

Ressalta-se que a questão é cultural, desenvolvida por uma educação que é dada desde a infância, em que o menino é criado para ser o macho "pegador”, e a menina para se resguardar. Uma tal educação está retratada no ditame popular: "Segure suas cabras que meu bode está solto", evidenciando bem a educação que se dá ao menino, para ser um caçador, e a menina a caça, que deve se proteger e se encastelar. Essa educação, imbricada nos valores culturais, naturaliza a conduta do homem estuprador e impõe à mulher uma vida de recato, no seu modo de vestir e de comportar socialmente para não provocar se colocar na condição de caça. A delegada que assumiu o caso, Cristiana Bento, retratou uma dessas situações em sua entrevista concedida ao jornal El pais, ao afirmar que:

Não é só a mulher, a criança também. As crianças vítimas de abuso, a primeira coisa que elas pensam é que são culpadas. Os próprios pais colocam isso. Uma mãe chegou a dizer para mim que falava para sua filha: "se alguém mexer na sua periquita, eu vou te bater". Num dado momento, o cara mexe e o que a criança pensa é que a culpa é dela por ter permitido, e pensa que se ela falar a mãe vai bater nela. Às vezes passa muito tempo até elas serem conscientes dos abusos e resolverem denunciar. Mas uma criança não esquece, aquilo deixa marca para o resto da vida. Tem que se falar, porque são muito alarmantes os casos de abuso sexual. ${ }^{25}$

Ficou evidente que a conduta da vítima do Rio de Janeiro, a qual - para os críticos de sua conduta social - foge aos padrões estabelecidos e aceitos, se tornou "merecedora" da violência sofrida. Essa percepção é estendida a toda menina que se comporte utilizando roupas curtas, com danças insinuantes, frequentadora de baladas e que bebe. Tais elementos são utilizados como instrumento de defesa dos acusados.

A configuração do delito, como já dito acima, ficou patente pela total incapacidade da vítima em decidir se queria ou não manter relações sexuais com todos aqueles homens, seja 30 ou menos abusadores, na medida em que o número interessa para identificação dos acusados, mas não para tipificação da conduta. Um ou trinta, o fato é que houve relações sexuais não consentidas, pela incapacidade da vítima para decidir sobre o ato. Para tal conduta existe previsão legal disciplinada no artigo 217-A, do Código Penal:

Art. 217-A. Ter conjunção carnal ou praticar outro ato libidinoso com menor de 14 (catorze) anos:

Pena - reclusão, de 8 (oito) a 15 (quinze) anos.

${ }^{25}$ MARTÍN, María. JIMÉNEZ, Carla. "O Brasil todo está falando da cultura do estupro hoje, mas ainda é pouco". El País - Brasil. (30/06/2016.). Disponível em: http://brasil.elpais.com/brasil/2016/06/27/politica/1467035241_416636.html. Acesso em: 04 jul. 2016. 
ISSN 1981-3694

(DOI): $10.5902 / 1981369431630$

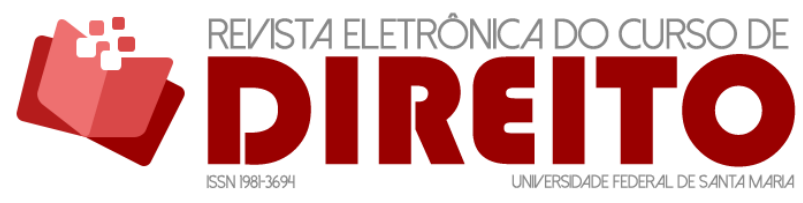

QUANDO A MORAL É ELEMENTO DETERMINANTE NAS DECISÕES SOBRE CRIMES DE VIOLÊNCIA SEXUAL: O SOLIPSISMO EPISTEMOLÓGICO

EdNA RAQuel HOGEMANN ACÁCIA GARDÊNIA SANTOS LELIS

§ 10 Incorre na mesma pena quem pratica as ações descritas no caput com alguém que, por enfermidade ou deficiência mental, não tem o necessário discernimento para a prática do ato, ou que, por qualquer outra causa, não pode oferecer resistência. ${ }^{26}$

No caso em estudo, a adolescente não tinha qualquer possibilidade de resistência e por essa razão a configuração do delito de estupro estaria plenamente evidenciada. Se o texto da lei estabelece que se configura estupro quando a vítima não pode oferecer resistência, basta este fato para que o ato configure crime. 0 delegado não poderia ter outro entendimento, pois estaria ele preso ao sentido expresso na norma, presente no caso em concreto. Como afirma Lênio Streck, tem-se que levar o texto a sério. Afirma ainda o autor que “[...] textos não são meros enunciados linguísticos; textos não são palavras ao vento, conceitos metafísicos que não digam respeito a algo (algo como algo)". ${ }^{27}$ Utilizar a reprovabilidade da vida pregressa da vítima como justificativa para não configuração do delito significa criar norma, relativizando a existente. Sob esse olhar, outros casos também receberam, de intérpretes do Direito, tratamento jurídico a partir de uma valoração moral, como o caso da absolvição do delegado de Polícia da cidade de Itu (SP), Moacir Rodrigues Mendonça, acusado de ter estuprado a própria neta de 16 anos de idade. Segundo informações do site da revista ISTO É, postado em data de 20 de maio de 2016,

\begin{abstract}
O delegado da Polícia Civil de São Paulo Moacir Rodrigues Mendonça foi absolvido pela Justiça da acusação de estupro contra a própria a neta, que tinha 16 anos na época da denúncia. 0 juiz Eduardo Luiz de Abreu Costa relatou, na sentença, que não havia 'prova segura' para condenação. Mendonça, que estava preso desde 2014, época da ocorrência, foi solto com a decisão. A promotoria de Olímpia, no interior paulista, anunciou que recorrerá da decisão. ${ }^{28}$
\end{abstract}

A absolvição do delegado, segundo se depreende do que foi noticiado pela imprensa nacional, ocorreu em razão da ausência de provas; não se considerou a ocorrência de uma relação sexual entre avô e neta, mas, sim, a ausência de resistência da vítima, ou seja, ausência de coação ou violência praticada pelo acusado. Nesse caso, o juiz entendeu pela reprovabilidade não da conduta do avô, mas sim da neta de 16 anos, por não ter resistido de forma suficiente à investida do avô, maior de 60 anos de idade.

26 BRASIL. Decreto-Lei 2.848 de 17 de dezembro de 1940. Código Penal. Disponível em: http://www.planalto.gov.br/ccivil_03/decreto-lei/Del2848compilado.htm. Acesso em: 12 dez. 2016.

27 STRECK, Lênio Luiz. 0 que é isso - decido conforme a minha consciência. Porto Alegre: Livraria do Advogado, 2010. p 219.

28 DELEGADO é absolvido de estupro da neta; 'não há prova segura', diz juiz. (20/05/2016). Isto É. (20/05/2016). ed. 245202.12 Disponível em: http://istoe.com.br/delegado-e-absolvido-de-estupro-daneta-nao-ha-prova-segura-diz-juizl. Acesso em 09 dez.2016. 
ISSN 1981-3694

(DOI): $10.5902 / 1981369431630$

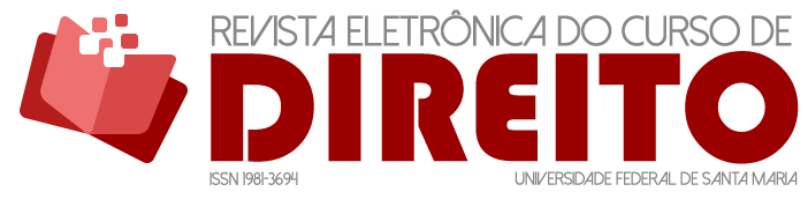

QUANDO A MORAL É ELEMENTO DETERMINANTE NAS DECISÕES SOBRE CRIMES DE VIOLÊNCIA SEXUAL: O SOLIPSISMO EPISTEMOLÓGICO

EDNA RAQUEL HOGEMANN ACÁCIA GARDÊNIA SANTOS LELIS

A sentença absolutória é fundamentada na ausência de comprovação de resistência de forma suficiente da vítima. É de se levantar, entretanto, quais critérios definem o que é resistência suficiente? Fica evidente que o juiz criou uma nova norma jurídica, ao inovar exigindo mais um elemento ao tipo penal, qual seja, resistência de forma suficiente, sendo essa baseada em valores intrínsecos à pessoa do juiz, perdendo, a norma, sua importância. Caberia ao juiz aplicar a subsunção do caso à norma, sem qualquer inovação, uma vez que este sequer poderia ser visto como um hard case,${ }^{29}$ implicando a aplicação imediata da regra jurídica.

Na mesma linha, salienta-se a violência praticada por um Promotor de Justiça, ao tomar o depoimento de uma adolescente de 13 anos de idade à época do crime, vítima de estupro praticado pelo próprio pai. Segundo noticiado no site de notícias $\mathrm{G1}$, na audiência, o promotor acusou a vítima de mentir sobre os fatos e a chamou de "criminosa", por ter feito um aborto, procedimento realizado com autorização judicial. Um exame de DNA no feto comprovou que o bebê era do pai da menina, resultado das relações sexuais forçadas. A Corregedoria do Ministério Público do Rio Grande do Sul decidiu investigar tanto a conduta do promotor de justiça da $7^{a}$ Câmara Criminal do Tribunal de Justiça, como a postura da juíza que conduziu a audiência. ${ }^{30}$

Nesse caso, também agiu o Ministério Púbico mediante solipsismo, de acordo com valores morais, e sua interpretação foi fundada em suas escolhas, esquecendo-se do texto da lei. o Código Penal autoriza o aborto em caso de estupro e, ao mesmo tempo, define como estupro de vulnerável se o ato sexual cometido por menor de 14 anos de idade. Não restava dúvida tanto de que a adolescente fora vítima de estupro, como que a lei autorizava o aborto, neste caso. Assim, a subsunção do fato à norma implicaria na autorização para o aborto. Indaga-se, então qual a razão da conduta do Ministério Público ofender a vítima em seu depoimento? Qual a interpretação que o mesmo fizera do fato? Criou o Ministério Público outra norma ainda não prevista? Vale ressaltar aquilo que Lênio Streck faz questão de repetir em suas obras, no sentido de não ser, o Direito, aquilo que o tribunal, no seu conjunto ou na individualidade de seus componentes, diz que é. ${ }^{31}$

29 Tradução: caso difícil (tradução livre das autoras).

30 FRAGA, Rafaella. PIRES, Estêvão. MP investiga promotor que chamou vítima de abuso sexual de mentirosa. (08/09/2016). G1. Disponível em: http://g1.globo.com/rs/rio-grande-dosul/noticia/2016/09/declaracoes-de-promotor-contra-vitima-de-estupro-causam-polemica.html. Acesso em: 12 dez. 2016.

31 STRECK, Lênio Luiz. Lições de crítica hermenêutica do direito. Porto Alegre: Livraria do Advogado, 2016. p. 16. 


\section{A MORAL COMO CONDICIONANTE DO DIREITO}

Em consonância com o relatado, a interpretação da norma jurídica foi balizada pelos valores morais dos intérpretes do Direito, tais como delegado, juiz e promotor de justiça. Com intuito de demonstrar que a conduta do delegado que deu início à investigação criminal do caso da adolescente vítima de estupro coletivo no Rio de Janeiro não é uma atitude isolada, foram trazidos, de forma sucinta, mais dois casos envolvendo dois diferentes intérpretes do Direito. As falas transcritas no presente estudo denotam o grau da subjetividade dos valores morais dos respectivos intérpretes do Direito. Os fundamentos para suas conclusões foram absolutamente pessoais e desprovidos da necessária fundamentação jurídica.

$\mathrm{Na}$ análise do Direito, a partir da subsunção do fato ao tipo penal que deve ser promovida por cada um dos respectivos intérpretes do Direito, faz-se necessário apresentar suas falas, e delas extrair a subjetividade dos valores morais nelas contidos. Para iniciar, transcrevese abaixo a fala do delegado Alessandro Thiers, segundo a Folha de São Paulo (30/05/2016), ao apresentar sua suspeita de que o caso não tratava de estupro, ao afirmar que "No Fantástico era outra pessoa. Sabe que temos fortes indícios de que não existiu estupro", e acrescentou ainda que “[...] diversas pessoas, inclusive a própria adolescente, confirmaram que a mesma frequentava a comunidade do Barão, inclusive com contato direto e intimo com traficantes da área". 32

Fica evidente que a conclusão do delegado decorre da sua percepção sobre o comportamento da vítima, uma vez que, por ser frequentadora da comunidade do Barão e ter relacionamentos com traficantes, não seria ela merecedora da condição de vítima. 0 delegado interpretou a norma jurídica com de modo subjetivo, quiçá arbitrário, quando valorou o comportamento da vítima como não merecedora da condição de vítima, naquela situação, ao sugerir falta de recato. Tal comportamento se configura numa imposição de um comportamento tradicional que limita a mulher em suas ações, estabelecendo como ela deve agir socialmente, no seu vestir, falar, dançar, exercer sua vida afetiva, o que impõe restrição a sua autonomia e liberdade individual. Não por acaso, Streck pondera que, para o Direito, “o intérprete do direito - seja ele o magistrado, o membro do Ministério Público, ou outro qualquer -, não é de sua

32 EM CONVERSA, delegado afastado diz ter 'indícios' de que não houve estupro. Folha de São Paulo. (30/05/2016). Disponível em: http://www1.folha.uol.com.br/cotidiano/2016/05/1776581-em-conversadelegado-diz-ter-fortes-indicios-de-que-nao-houve-estupro.shtml. Acesso em: 12 dez. 2016. 
ISSN 1981-3694

(DOI): $10.5902 / 1981369431630$

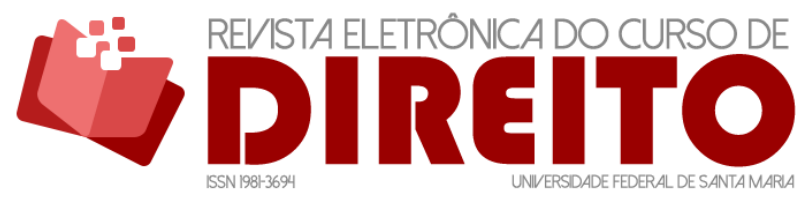

QUANDO A MORAL É ELEMENTO DETERMINANTE NAS DECISÕES SOBRE CRIMES DE VIOLÊNCIA SEXUAL: O SOLIPSISMO EPISTEMOLÓGICO

EDNA RAQUEL HOGEMANN ACÁCIA GARDÊNIA SANTOS LELIS

subjetividade que deverá emanar ou fluir o sentido a ser atribuído à norma jurídica a ser aplicada ao caso em análise."33

O caso sob exame ressalta com exatidão uma violação patente aos preceitos mais basilares da aplicação da teoria da norma jurídica, na medida em que o que caracteriza a norma jurídica é o fato de se tratar de preceito de ordem geral, que obriga a todos que se acham em igual situação jurídica, ou seja, é de ordem geral. Da generalidade da norma deduz-se o princípio da isonomia da lei, segundo o qual todos são iguais perante a lei. Razão pela qual pouco importa se se trata de uma menina, de uma prostituta ou de uma dona de casa, se houve conjunção carnal não consentida e com violência é estupro. Assim também, as normas jurídicas visam estabelecer uma fórmula padrão de conduta aplicável a qualquer membro da sociedade, por isso mesmo se caracterizam pela abstratividade. A letra da norma penal não faz qualquer referência à vida pregressa da vítima. Tanto faz que ela tenha tido algum tipo de relacionamento anterior com maus elementos ou coisa que o valha.

No caso do juiz que absolveu o delegado, sua fundamentação sobre inexistência do tipo penal de estupro decorreu da insuficiência de comprovada resistência da vítima em relação ao avô, conforme se depreende de sua fala,

A não anuência à vontade do agente, para a configuração do crime de estupro, deve ser séria, efetiva, sincera e indicativa de que o sujeito passivo se opôs, inequivocadamente, ao ato sexual, não bastando a simples relutância, as negativas tímidas ou a resistência inerte. Não há prova segura e indene de que o acusado empregou força física suficientemente capaz de impedir a vítima de reagir. A violência material não foi asseverada, nem esclarecida. A violência moral, igualmente, não é clarividente, penso. ${ }^{34}$

Não distante da mesma percepção do delegado, nessa direção também foi o promotor de justiça, Dr. Theodoro Alexandre da Silva Silveira, ao tomar o depoimento da adolescente estuprada pelo pai: “(...) Tu fez eu e a juíza autorizar um aborto e agora tu te arrependeu assim? Pra abrir as pernas (...) pra um cara tu tem maturidade (...) e pra assumir uma criança tu não tem?" (sic - supressões no original). ${ }^{35}$

33 STRECK, Lênio Luiz. Lições de crítica hermenêutica do direito. Porto Alegre: Livraria do Advogado, 2016. p.94.

34 DELEGADO é absolvido de estupro da neta; 'não há prova segura', diz juiz. (20/05/2016). Isto É. (20/05/2016). ed. 245202.12 Disponível em: http://istoe.com.br/delegado-e-absolvido-de-estupro-daneta-nao-ha-prova-segura-diz-juiz/. Acesso em 09 dez.2016.

35 FRAGA, Rafaella. PIRES, Estêvão. MP investiga promotor que chamou vítima de abuso sexual de mentirosa. (08/09/2016). G1. Disponível em: http://g1.globo.com/rs/rio-grande-dosul/noticia/2016/09/declaracoes-de-promotor-contra-vitima-de-estupro-causam-polemica.html. Acesso em: 12 dez. 2016. 
ISSN 1981-3694

(DOI): $10.5902 / 1981369431630$

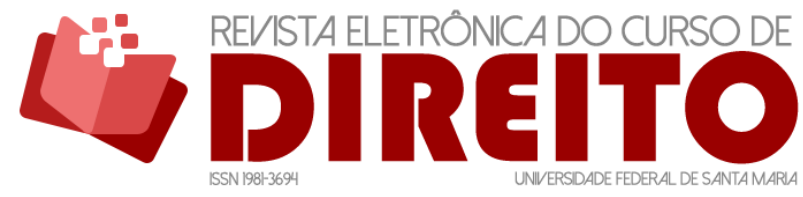

QUANDO A MORAL É ELEMENTO DETERMINANTE NAS DECISÕES SOBRE CRIMES DE VIOLÊNCIA SEXUAL: O SOLIPSISMO EPISTEMOLÓGICO

EDNA RAQUEL HOGEMANN ACÁCIA GARDÊNIA SANTOS LELIS

Para compreender a ausência de autonomia e a restrição da liberdade da mulher, faz-se necessário compreender qual a condição sociojurídica da mulher na sociedade. Inicialmente, o Código Civil de 1916, em sua redação original, posicionava a mulher em condição de completa submissão ao marido, ou seja, de inferioridade, considerada incapaz civilmente, condição essa relatada por Zélia Pinho Rezende em seu depoimento junto à Comissão Parlamentar de Inquérito, ao afirmar que:

O nosso Código era uma aberração. A mulher casada ficava inteiramente sob o poder do marido. Passava a relativamente incapaz, em pior situação do que os índios, do que os menores, porque os menores, à medida que eles iam ganhando a idade, tornavam-se emancipados. Os silvícolas, a que as mulheres casadas eram equiparadas, à medida que fossem se integrando à civilização tornavam-se emancipados: a mulher casada nunca. ${ }^{36}$

A condição da mulher estabelecida pela redação original do Código Civil de 1916 foi alterada posteriormente pelo Estatuto da Mulher casada, Lei 4.121, de 27 de agosto de 1962. Várias outras normas foram editadas em nível internacional e nacional, com o propósito de instituir a igualdade de direitos entre homens e mulheres, como, por exemplo, a Declaração Sobre Eliminação da Discriminação contra a Mulher $^{37}$ aprovada pela Organização das Nações Unidas e a Constituição Federal de 1988 a qual estabelece em seu artigo $5^{\circ}$ a igualdade de todos perante a lei. ${ }^{38}$

A igualdade entre homens e mulheres estabelecida na Constituição de 1988 já era declarada nas constituições anteriores, porém a interpretação que se dava não assegurava a inclusão plena das mulheres. Para que essa igualdade se estendesse às mulheres, segundo Zélia Rezende, foi necessário o parecer de Ruy Barbosa declarando que cidadão brasileiro era homem e mulher, que cidadão não era só homem. ${ }^{39}$

\footnotetext{
${ }^{36}$ BRASIL. SENADO FEDERAL. Relatório final da Comissão Parlamentar de Inquérito da Mulher. Brasília: Senado Federal, Centro Gráfico, 1978. p. 204. Disponível em: https://www2.senado.leg.br/bdsf/bitstream/handle/id/84968/CPMIMulher.pdf?sequence=4. Acesso em: 16 jun. 2019.

37 ORGANIZAÇÃO DAS NAÇÕES UNIDAS (ONU). Declaração sobre a Eliminação da Discriminação contra a Mulher. Proclamada pela Assembleia Geral na Resolução 2263(XXII), de 7 de novembro de 1967 em: Disponível em: http://www.unicef.org/brazil/pt/resources_10233.htm. Acesso em: 19 jun. 2016.

38 BRASIL. Constituição 1988 e ADCT. Constituição da República Federativa do Brasil, de 5 de outubro de 1988. Brasília, DF: Presidência da República. Disponível em: http://www.planalto.gov.br/ccivil_03/constituicao/constituicao.htm. Acesso em: 16 jun. 2019.

39 BRASIL. SENADO FEDERAL. Relatório final da Comissão Parlamentar de Inquérito da Mulher. Brasília: Senado Federal, Centro Gráfico, 1978. p. 204. Disponível em: https://www2.senado.leg.br/bdsf/bitstream/handle/id/84968/CPMIMulher.pdf?sequence=4. Acesso em: 16 jun. 2019.
} 
ISSN 1981-3694

(DOI): $10.5902 / 1981369431630$

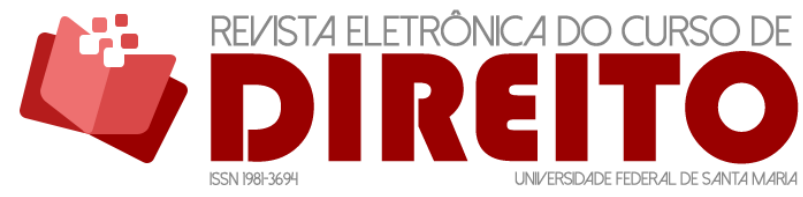

QUANDO A MORAL É ELEMENTO DETERMINANTE NAS DECISÕES SOBRE CRIMES DE VIOLÊNCIA SEXUAL: O SOLIPSISMO EPISTEMOLÓGICO

EDNA RAQUEL HOGEMANN ACÁCIA GARDÊNIA SANTOS LELIS

Apesar das inovações legislativas, a igualdade ficou no campo formal, e, na prática, não se efetivou. Paulatinamente, foi reconhecido à mulher o direito de exercer todas as atividades na esfera pública e privada, mas ela não ganhou, de imediato, o reconhecimento social de sua condição de igualdade em relação ao homem.

A desigualdade não se restringia à esfera legal e jurídica, mas principalmente à esfera social privada, a exemplo de sua sexualidade. A sexualidade feminina historicamente foi resignada ao interesse do homem. A marginalização sexual das mulheres está arraigada nos ditames históricos e culturais, uma vez que elas são educadas por mulheres, numa sociedade em que a virilidade e o prestígio do macho estão longe de ser apagados. ${ }^{40}$ Meninas são orientadas a atuar como filhas e mães, mas não como mulheres. E, sobre essa construção simbólica, complementa Simone Beauvoir: “[...] o opressor não seria tão forte se não tivesse cúmplices entre os próprios oprimidos". ${ }^{41}$ A cultura machista é privilégio do homem, mas as mulheres são também educadas com esses mesmos valores, de modo que contribuem a perpetuá-lo.

As construções simbólicas que impõem a homens e mulheres determinados papéis, identificando-os dentro de sua cultura, acabam por limitar as potencialidades dos gêneros, criando rotulações sobre o que seria ou não permitindo a cada um deles no âmbito social. Essa construção decorre do sistema patriarcal, que Heleieth Saffioti afirma se referir a milênios da história mais próxima nos quais se implantou uma hierarquia entre homens e mulheres, com primazia masculina. ${ }^{42}$

Desde a infância, esses agentes são orientados para valores culturais opostos. Assim, enquanto os meninos são educados para o uso da força física, valorização da agressividade, ações de dominação e realização, ainda precoce, de sua vida sexual, as meninas são conduzidas pelo caminho da submissão, passividade e sentimentalismo, ou seja, a sua valorização está diretamente ligada à feminilidade, dependência e capacidade de sedução. 0 comportamento da mulher deve atender, assim, a essa submissão, que the importa uma consideração social de respeito e valorização.

Dessa forma, a moralidade da mulher encontra-se circunscrita ao seu comportamento social, que atende à imposição social na forma de se vestir, de se portar, nas suas relações pessoais monogâmicas e voltadas à família. Essa condição cria, em muitos casos, um

${ }^{40}$ GOIS, M.M.S. Aspectos históricos e sociais da anticoncepção. Reproduo, v. 6, n. 3, p. 119-24, 1991. p. 119.

${ }^{41}$ BEAUVOIR, Simone de. 0 segundo sexo - Fatos e mitos. São Paulo: Difusão Europeia do Livro, 2005. p. 82.

42 SAFFIOTI, Heleieth lara Bongiovani. Gênero, patriarcado e violência. São Paulo: Fundação Perseu Abramo, 2004. p. 123. 
ISSN 1981-3694

(DOI): $10.5902 / 1981369431630$

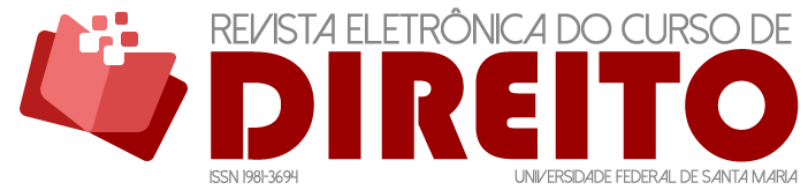

QUANDO A MORAL É ELEMENTO DETERMINANTE NAS DECISÕES SOBRE CRIMES DE VIOLÊNCIA SEXUAL: O SOLIPSISMO EPISTEMOLÓGICO

EDNA RAQUEL HOGEMANN ACÁCIA GARDÊNIA SANTOS LELIS

comportamento social artificial, não condizente com a autêntica forma de pensar e sentir da mulher contemporânea, pois, muitas vezes, não importa o que ela pensa, mas o que a sociedade - em especial, os homens - pensa sobre ela. Como afirma Wollstonecraft:

\begin{abstract}
"As mulheres", disse certo autor, não me recordo qual, "não se preocupam com aquilo que somente o Céu vê". Por que, de fato, deveriam fazê-lo? É o olho do homem que elas aprenderam a temer-e, se elas podem ninar seu Argos, ${ }^{43}$ raramente pensam no Céu ou nelas mesmas, porque sua reputação está salva; é a reputação, e não a castidade, com todos seus belos acompanhamentos, que elas empregam para se manter livres de mácula, não como uma virtude, mas para preservar sua posição no mundo. ${ }^{44}$
\end{abstract}

Esse padrão de comportamento, quando não atendido, acaba por revelar o discurso machista e sexista que, a despeito de estar-se sob as luzes de um novo milênio, não se encontra totalmente ultrapassado. Como afirma Massoneto, nos casos noticiados de estupro nos últimos anos, ficou claro que as mulheres não são vistas como seres com vontade própria, são consideradas propriedade dos homens. Afirma ainda a autora que cabe às mulheres obedecerem às regras masculinas - ser feminina, falar baixo, aceitar ser vista como objeto sexual, pois "homem é assim mesmo". ${ }^{45}$ E quem não aceita as tais "regras masculinas" é culpada por tudo o que the vier a acontecer.

Destaca-se, ainda, que o estupro é uma ofensa aos direitos humanos, porque fere o princípio angular da dignidade humana, ao preterir a autodeterminação do ser humano e sua capacidade de ter uma vida plena, com direito à integridade física e psíquica, e ao não permitir a sua autorrealização no aspecto individual e social. A dignidade do outro estará sempre vinculada ao reconhecimento recíproco de que o ser humano não pode ser degradado ou coisificado, o que constitui a base da conivência humana em sociedade. ${ }^{46}$

\footnotetext{
${ }^{43}$ Gigante de Cem olhos, personagem da mitologia grega. (WOLLSTONECRAFT, Mary. Reivindicação dos direitos da mulher. Tradução Ivania Pocinho Motta. São Paulo: Boitempo, 2016. p. 171.)

${ }^{44}$ WOLLSTONECRAFT, Mary. Reivindicação dos direitos da mulher. Tradução Ivania Pocinho Motta. São Paulo: Boitempo, 2016. p 31.

45 MASSONETTO, Grazi. O silencio que ecoa: a cultura do estupro no Brasil. Lugar de Mulher. (05/10/2015). P. 35. Disponível em: http://lugardemulher.com.br/o-silencio-que-ecoa-a-cultura-doestupro-no-brasil. Acesso em 03 jul 2016.

${ }^{46}$ SOARES, Ricardo Mauricio Freire. 0 princípio constitucional da dignidade pessoa humana. São Paulo: Saraiva, 2010, p. 23.
} 


\section{CONCLUSÃO}

O Direito concebido como ciência social, se por um lado deve acompanhar as mudanças que ocorrem na sociedade, a fim de tutelar os novos direitos ou prevenir novos conflitos, apontando solução para os conflitos inevitáveis, por outro tem a tarefa de conservar e proteger os valores consagrados, as vulnerabilidades. Isso porque, como um produto cultural, o Direito, é influenciado e reflete a realidade social, econômica e política que o envolve.

De todo modo, não se pode olvidar a mudança acelerada verificada desde o último século XX, colocando na ordem do dia a importância do ser humano e sua dignidade, consagrados nos documentos internacionais relativos aos Direitos Humanos, que conduziu a uma tomada de consciência da necessidade de defesa de interesses de todos, a começar pelos que interferem na qualidade de vida.

Ao se considerar o estupro como uma consequência natural do comportamento da vítima, compreender que uma mulher fora dos padrões comportamentais estabelecidos pela sociedade seja "merecedora" de ser estuprada é, além de outras questões, uma violação dos princípios éticos e morais de qualquer sociedade civilizada.

0 presente trabalho demonstra que intérpretes e aplicadores do Direito não podem decidir tendo como referencial condicionante da norma as suas consciências, sua subjetividade, vez que podem vir a se contrapor ao direito e à democracia. Nos casos apresentados ao longo desse estudo, houve flagrante incompatibilidade entre o exercício das liberdades individuais, a natural tendência de não lesividade a si mesmo e a renúncia compulsória à sua identidade, em prol de um modelo de comportamento idealizado, etéreo e inatingível.

Dessa forma, aplicando os ensinamentos defendidos por Streck, evidencia-se a necessidade da mudança do comportamento dos intérpretes do Direito, que devem decidir em conformidade com a lei, ainda que suas ideias e convicções sejam permeadas por valores diversos. O primeiro passo é reconhecer que se vive numa sociedade complexa de cariz patriarcal e dominado pelo signo do macho proprietário e patrimonialista. Por tais razões, no que diz respeito à importância de uma interpretação da norma promotora de justiça, inequívoco o contributo da hermenêutica universal de Schleiermacher, na medida em que o interprete da norma deve ter em conta sua vinculação ao ordenamento jurídico como um todo, para que possa, nos marcos do próprio ordenamento, alcançar seu sentido de construção do justo. Reproduzir a desigualdade entre homens e mulheres é perpetuar a intolerância e o atraso. É 
ISSN 1981-3694

(DOI): $10.5902 / 1981369431630$

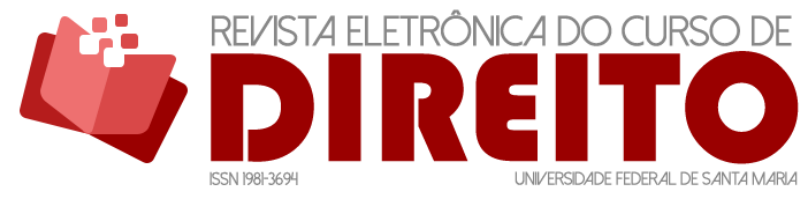

QUANDO A MORAL É ELEMENTO DETERMINANTE NAS DECISÕES SOBRE CRIMES DE VIOLÊNCIA SEXUAL: O SOLIPSISMO EPISTEMOLÓGICO

EdNA RAQuel HOGEMANN ACÁCIA GARDÊNIA SANTOS LELIS

involuir, contrariando qualquer senso de justiça e perpetuando um pensamento primitivo de dominação, que representa valores abjetos e, portanto, inaceitáveis.

\section{REFERÊNCIAS}

BEAUVOIR, Simone de. 0 segundo sexo - Fatos e mitos. São Paulo: Difusão Europeia do Livro, 2005.

BOURDIEU, Pierre. A dominação masculina. 2. ed. Tradução Maria Helena Kühner. Rio de Janeiro: Bertrande Brasil, 2002.

BRASIL. Constituição 1988 e ADCT. Constituição da República Federativa do Brasil, de 5 de outubro de 1988. Brasília, DF: Presidência da República. Disponível em:

http://www.planalto.gov.br/ccivil_03/constituicao/constituicao.htm. Acesso em: 16 jun. 2019.

BRASIL. Decreto-Lei 2.848 de 17 de dezembro de 1940. Código Penal. Disponível em:

http://www.planalto.gov.br/ccivil_03/decreto-lei/Del2848compilado.htm. Acesso em: 12 dez. 2016.

BRASIL. SENADO FEDERAL. Relatório final da Comissão Parlamentar de Inquérito da Mulher. Brasília: Senado Federal, Centro Gráfico, 1978. Disponível em:

https://www2. senado.leg.br/bdsf/bitstream/handle/id/84968/CPMIMulher.pdf?sequence=4. Acesso em: 16 jun. 2019.

CHAUÍ, Marilena. Convite à Filosofia. 3. Ed. São Paulo: Ática, 1995.

COMENTÁRIO de Lobão sobre estupro gera polêmica: 'País que fabrica miniputas'. Diário de Pernambuco. (27/05/2016). Disponível em:

http://www.diariodepernambuco.com.br/app/noticia/divirtase/46,51,46,61/2016/05/27/intern as_viver,647160/comentario-de-lobao-sobre-estupro-gera-polemica-pais-que-fabrica-min.html. Acesso em 04 jul. 2016.

DELEGADO é absolvido de estupro da neta; 'não há prova segura', diz juiz. (20/05/2016). Isto É. (20/05/2016). ed. 245202.12 Disponível em: http://istoe.com.br/delegado-e-absolvido-deestupro-da-neta-nao-ha-prova-segura-diz-juiz/. Acesso em 09 dez. 2016.

DWORKIN, Ronald. A Justiça de toga. São Paulo: Martins Fontes, 2010.

EM CONVERSA, delegado afastado diz ter 'indícios' de que não houve estupro. Folha de São Paulo. (30/05/2016). Disponível em: http://www1.folha.uol.com.br/cotidiano/2016/05/1776581-emconversa-delegado-diz-ter-fortes-indicios-de-que-nao-houve-estupro.shtml. Acesso em: 12 dez. 2016. 
ISSN 1981-3694

(DOI): $10.5902 / 1981369431630$

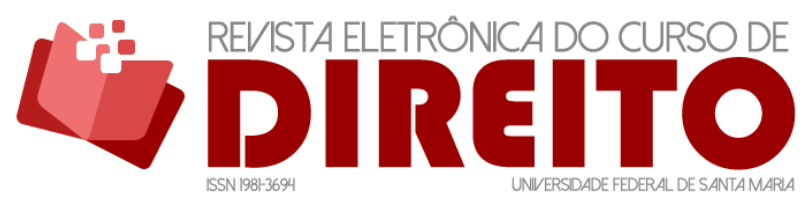

QUANDO A MORAL É ELEMENTO DETERMINANTE NAS DECISÕES SOBRE CRIMES DE VIOLÊNCIA SEXUAL: O SOLIPSISMO EPISTEMOLÓGICO

EdNA RAQuel HOGEMANN ACÁCIA GARDÊNIA SANTOS LELIS

FRAGA, Rafaella. PIRES, Estêvão. MP investiga promotor que chamou vítima de abuso sexual de mentirosa. (08/09/2016). G1. Disponível em: http://g1.globo.com/rs/rio-grande-dosul/noticia/2016/09/declaracoes-de-promotor-contra-vitima-de-estupro-causam-polemica.html. Acesso em: 12 dez. 2016.

G1. 'O próprio delegado me culpou', diz menor que sofreu estupro no Rio. Entrevista concedida a Renata Ceribelli, exibida no Fantástico em 29/05/2016. G1 Rio. (29/05/2016). Disponível em: http://g1.globo.com/rio-de-janeiro/noticia/2016/05/o-proprio-delegado-meculpou-diz-menor-que-sofreu-estupro-no-rio.html. Acesso em: 04 jul. 2016.

G1. Vítima de estupro coletivo no Rio conta que acordou dopada e nua. Disponível em: http://g1.globo.com/rio-de-janeiro/noticia/2016/05/vitima-de-estupro-coletivo-no-rio-contaque-acordou-dopada-e-nua.html. Acesso em: 10 maio 2017.

GOIS, M.M.S. Aspectos históricos e sociais da anticoncepção. Reproduo, v. 6, n. 3, p. 119-24, 1991.

HOGEMANN, Edna Raquel. Sociologia jurídica e judiciária. Rio de Janeiro: SESES, 2015.

LEITÃO, Leslie. Polícia tenta identificar bandidos que praticaram estupro coletivo em favela do Rio de Janeiro. Veja.com. (26/05/2016). Disponível em:

http://veja.abril.com.br/noticia/brasil/policia-tenta-identificar-bandidos-que-praticaramestupro-coletivo-em-favela-do-rio-de-janeiro. Acesso em: 04 jul. 2016.

LOBÃO. NUM PAÍS QUE SE FABRICA MINI-PUTAS,COM UMA FARTA EROTIZAÇÃO PRECOCE E COM SEVERA INFANTILIZAÇÃO DA POPULAÇÃO REDUZINDO AS RESPONSABILIDADES. [Local], 26 maio 2016. Twitter: @lobaoeletrico. Disponível em:

https://twitter.com/lobaoeletrico/status/735983496104189952. Acesso em: 16 jun. 2019.

MARTÍN, María. JIMÉNEZ, Carla. O Brasil todo está falando da cultura do estupro hoje, mas ainda é pouco. El País - Brasil. (30/06/2016.). Disponível em:

http://brasil.elpais.com/brasil/2016/06/27/politica/1467035241_416636.html. Acesso em: 04 jul. 2016.

MARTINS, Nayla Louhana de Sá; STIVAL, Mariane Morato. Uma análise feminista: Estamos livres? Padrões de beleza, objetificação do corpo feminino e cultura de estupro. (2016). ISSUU.

Disponível em: https://issuu.com/esmpgo/docs/19-artigo21_final_layout_1. Acesso em: 04 jul. 2016.

MASSONETTO, Grazi. O silencio que ecoa: a cultura do estupro no Brasil. Lugar de Mulher. (05/10/2015). Disponível em: http://lugardemulher.com.br/o-silencio-que-ecoa-a-cultura-doestupro-no-brasil. Acesso em 03 jul 2016.

MORA, José Ferrater. Diccionario de Filosofía. Barcelona: Ariel, 2001.

ORGANIZAÇÃO DAS NAÇÕES UNIDAS (ONU). Declaração sobre a Eliminação da Discriminação contra a Mulher. Proclamada pela Assembleia Geral na Resolução 2263(XXII), de 7 de novembro de 1967 em: Disponível em: http://www.unicef.org/brazil/pt/resources_10233.htm. Acesso em: 19 jun. 2016. 
PIMENTEL, Silvia. DI GIORGI, Beatriz. PIOVESAN, Flávia. A Figura/Personagem Mulher em Processos de Família. Porto Alegre: Fabris, 1993.

SAFFIOTI, Heleieth lara Bongiovani. Gênero, patriarcado e violência. São Paulo: Fundação Perseu Abramo, 2004.

SCHLEIERMACHER, Friedrich D.E. Hermenêutica: arte e técnica da interpretação. 5. ed.Trad. Celso Reni Braida. Bragança Paulista: Editora Universitária São Francisco, 2006.

SOARES, Ricardo Mauricio Freire. O princípio constitucional da dignidade pessoa humana. São Paulo: Saraiva, 2010.

STRECK, Lênio Luiz. Lições de crítica hermenêutica do direito. Porto Alegre: Livraria do Advogado, 2016.

STRECK, Lênio Luiz. 0 que é isso - decido conforme a minha consciência. Porto Alegre: Livraria do Advogado, 2010.

VEJA. MP denuncia quatro por estupro coletivo no Rio. Disponível em: http://veja.abril.com.br/noticia/brasil/mp-denuncia-quatro-por-estupro-coletivo-no-rio. Acesso em: 04 jul. 2016.

WOLLSTONECRAFT, Mary. Reivindicação dos direitos da mulher. Tradução Ivania Pocinho Motta. São Paulo: Boitempo, 2016.

\section{COMO FAZER REFERÊNCIA AO ARTIGO (ABNT):}

HOGEMANN, Edna Raquel; LELIS, Acácia Gardênia Santos. Quando a moral é elemento determinante nas decisões sobre crimes de violência sexual: o solipsismo epistemológico. Revista Eletrônica do Curso de Direito da UFSM, Santa Maria, RS, v. 14, n. 2, e31630, maio./ago. 2019. ISSN 1981-3694. DOI:

http://dx.doi.org/10.5902/1981369431630. Disponível em:

https://periodicos.ufsm.br/revistadireito/article/view/31630 Acesso em: dia mês. ano.

Direitos autorais 2019 Revista Eletrônica do Curso de Direito da UFSM

Editores responsáveis: Rafael Santos de Oliveira e Angela Araujo da Silveira Espindola

Internacional. 
ISSN 1981-3694

(DOI): $10.5902 / 1981369431630$

\section{SOBRE AS AUTORAS}

\section{EDNA RAQUEL HOGEMANN}

Pós-Doutora em Direito, pela Universidade Estácio de Sá/RJ, Doutora em Direito pela Universidade Gama Filho - UGF (2006), Mestre em Direito pela Universidade Gama Filho - UGF (2002), Pós-Graduação Lato Sensu em Bioética, pela Red Bioética UNESCO (2010), Pós-Graduação Lato-Sensu em História do Direito Brasileiro, pela Universidade Estácio de Sá - UNESA (2007), Graduada em Jornalismo, pela Universidade Federal do Rio de Janeiro - UFRJ (1977) e Bacharel em Direito pela Universidade do Grande Rio (1999). Professora Adjunta III do Curso de Direito, da Universidade Federal do Estado do Rio de JaneiroUniRio. Professora Permanente do Programa de Pós Graduação Stricto Sensu, em Direito, da Universidade Estácio de Sá UNESA/RJ . Além de pesquisadora junto à FAPERJ, em projetos de pesquisa sobre convivência e de mediação familiar com crianças/adolescentes acolhidos institucionalmente e em projetos de iniciação científica e de extensão universitária, em convênio com o Ministério Público do Estado do Rio de Janeiro. Tem experiência na área de Direito, com ênfase em Teoria do Direito, atuando principalmente nos seguintes temas: Direitos humanos, Teoria do Direito - História Social do Direito Novos Direitos ( Bioética - Biodireito, Direitos da Personalidade, Formas adequadas de solução de conflitos e EAD ) nas áreas de pós-graduação stricto e lato sensu

\section{ACÁCIA GARDÊNIA SANTOS LELIS}

Advogada, Doutoranda em Direito pela linha de pesquisa Direitos Fundamentais e Novos Direitos pela Sociedade Superior Estácio de Sá (RJ); Mestre em Direito pela PUC (PR), do Programa de Direito Econômico e Socioambiental; Especialista em Direito Processual pela Universidade Federal de Sergipe; Conselheira Seccional da Ordem dos Advogados do Brasil (SE); Presidente da Comissão dos Direitos da Criança e do Adolescente da OAB/SE; Presidente Estadual do Instituto Brasileiro de Direito de Família (IBDFAM/SE); Professora do Curso de Direito da Universidade Tiradentes (SE); Professora do curso de Direito da Faculdade Pio Décimo e membro do Núcleo Docente Estruturante (NDE), Avaliadora de Trabalhos do Conpedi nos anos de 2017 e 2018; integrante do grupo de pesquisa sobre a mulher e a família da Faculdade Tiradentes, como atuação na área do Direito de Família, da Infância e Violência Doméstica e Intrafamiliar. 